\title{
The Effect of Different Levels of Zinc on Morpho-Physiological Parameters, Seed Yield Attributing Characters and Seed Quality of Wheat
}

\author{
Devendra Kumar Singh ${ }^{1}$, Meera Shrivastava', Vivek Kumar Patel ${ }^{2}$, \\ Ankit Singh $^{3 *}$ and Abhay Kumar ${ }^{4}$ \\ ${ }^{1}$ Department of Seed Science, Chandra Shekhar Azad University of Agriculture and \\ Technology, Kanpur (Uttar Pradesh) - 208002, India \\ ${ }^{2}$ Department of Soil Science and Agricultural Chemistry, Acharya Narendra Deva University \\ of Agriculture and Technology Kumarganj, Ayodhya (Uttar Pradesh) - 224229, India \\ ${ }^{3}$ Department of Agronomy, Dr. Rajendra Prasad Central Agricultural University, \\ Pusa, Samastipur (Bihar) - 848125, India \\ ${ }^{4}$ Department of Agricultural Biotechnology and Molecular Biology, Dr. Rajendra Prasad \\ Central Agricultural University, Pusa, Samastipur (Bihar) - 848125, India \\ *Corresponding author
}

\begin{tabular}{l} 
Ke y w o r d s \\
$\begin{array}{l}\text { Crop varieties, } \\
\text { chemical fertilizers, } \\
\text { quality of grain }\end{array}$ \\
Article Info \\
$\begin{array}{l}\text { Accepted: } \\
15 \text { April } 2020 \\
\text { Available Online: } \\
\text { 10 May } 2020\end{array}$ \\
\hline
\end{tabular}

\section{A B S T R A C T}

Intensive and multiple cropping, cultivations of crop varieties with heavy nutrient requirement and unbalanced use of chemical fertilizers especially nitrogen and phosphorus fertilizers reduced quality of grain production and the appearance of micronutrient deficiency in crops. Experiment was conducted on variety K307 and K1006. Five doses of zinc viz. $0.0 \%, 0.5 \%, 1 \%, 1.5 \%$ and $2 \%$ zinc solution were sprayed at two stages of crop i.e. $60 \& 90$ DAS was applied. Observations were recorded on morph-physiological characters, yield and yield attributing characters. Result showed that the application of zinc affected significantly to all the parameters except days to heading, chlorophyll intensity, chlorophyll fluorescence, plant height, spike length and leaf area index at 60 and 90 DAS, number of tillers per $\mathrm{m}^{-2}$, seed yield per plot, 1000 seed weight, standard germination per cent, seedling length and seedling vigour index and most of the yield and quality related parameters were significantly affected by application of $2 \%$ zinc solution have been found to be most appropriate for increasing seed yield and seed quality of wheat variety K307 and K1006. Variety K1006 was found better and superior for grain yield per plot, number of tillers $\mathrm{m}^{-2}$, number of seed per spike and other yield attributing parameters. 


\section{Introduction}

Wheat (Triticum aestivum L.) is the leading food crop in world farming. It is main food crop in temperate zone and extended up to warm regions of temperate and sub tropics to tropical low lands. One of the most ancient crop of the world. Wheat is the second most important staple food next to rice, consumed by nearly $35 \%$ of the world population and providing $20 \%$ of the total food calories. Wheat occupies about $32 \%$ of the total acreage under cereals in the world. The main wheat growing countries include China, India, USA, Russia, France, Canada, Germany, Turkey, Australia and Ukraine. In India, wheat is mainly grown in the states of Uttar Pradesh, Madhya Pradesh, Punjab, Rajasthan, Haryana, Bihar, Maharashtra, Karnataka and Gujarat. Globally, probable demand for wheat by the year 2020 is forecast at around 950 million tonnes per year. This target will be achieved only, if global wheat production is increased by $2.5 \%$ per annum.

The importance of micronutrients application in increasing crop production has been recognized in India and it is becoming evident that without the use of the micronutrient, it is not possible to get the maximum benefits of NPK fertilizers and high yielding varieties of wheat (Shukla and Warsi, 2000). the growth and yield of plant is determine by the availability of some specific mineral nutrients that are absolutely essential for the completion of their life cycle (Marshner, 1995) .excess or deficiency of certain elements from the crop can affect its yield, quality and subsequent post-harvest life .

Zinc is an essential micronutrient for plant growth and is absorbed by the plant roots in the form of $\mathrm{Zn}^{2+}$. It is involved in Fhydrogenase and carbonic anhydrase, synthesis of cytochrome and the stabilization of ribosomal fractions and auxin metabolism
(Tisdale et al., 1984). Zinc deficiency also decreases nutritional quality of wheat grain and contributes to health problems in human beings, mainly in developing countries where cereals are major steple food (Kalayci et al., 1999).

Any deficiency of zinc in the soil affects crop metabolic activity and resulted in poor grain yield. The $\mathrm{Zn}$ mobility in plants causes some intervenalchlorosis mostly in the younger leaves. Both high and low zinc are disadvantageous for growing crops. Owing due to high demand of zinc by rice plant, a little amount of zinc is left in the soil which is supposed to be least available to wheat crop. Under such circumstances growth yielding ability and seed quality of wheat is badly affected. Hence, it is obvious to find out suitable level of zinc requirement for optimal growth, better yield and seed quality of the crop.

\section{Materials and Methods}

The experiment was conducted at Nawabganj Farm, Kanpur during the year 2017-18 and seed quality was assessed in the laboratory of the department of seed science and technology, Chandra Shekhar Azad university of Agriculture and technology, Kanpur to investigate Effect of foliar application of zinc on seed yield and quality of wheat seed (Triticum aestivum L.). The experimental design was a Factorial randomized complete block design with three replicates. Treatments were control two varieties and five $\mathrm{Zn}$ Application- $0.0 \% \mathrm{Zn}, 0.5 \% \mathrm{Zn}, 1.0 \% \mathrm{Zn}$, $1.50 \% \mathrm{Zn}, 2.0 \%$ Parameters such as grain yield ( $\mathrm{kg} / \mathrm{ha})$, seed $\mathrm{Zn}$ concentration $(\mathrm{mg} / \mathrm{kg}$ ) were evaluated. Nawabganj Farm, Kanpur is situated in the Gangetic alluvial belt of central uttar Pradesh and located between $25^{\circ} 26^{\prime}$ to $26^{\circ} 28^{\prime}$ North Latitude and $79^{\circ} 31^{\prime}$ to $80^{\circ} 34^{\prime}$ East Longitude at elevation of 127.00 meter above Mean Sea Level. 


\section{Days to heading}

Days taken for heading were recorded from the date of sowing in each treatment of every replication separately.

\section{Plant height}

Ten plants were selected randomly at the time of maturity in each treatment of every replication. Plant height was measured from the base of the plants to the tip of the panicle and expressed in $\mathrm{cm}$.

\section{Leaf area index (LAI)}

Leaf Area Index was calculated by formula given by Watson (1947).

$\mathrm{LAI}=\mathrm{LA} / \mathrm{P}$

Where,

LA $=$ Leaf Area

$\mathrm{P}=$ Occupied Land Area

\section{Chlorophyll intensity (CI)}

Chlorophyll Intensity was determined by chlorophyll meter SPAD 502.

\section{Chlorophyll fluorescence (CF)}

Chlorophyll Fluorescence was measured by Pulse Amplified Portable Chlorophyll Meter.

\section{Number of Tillers sqm ${ }^{-1}$}

In the centre of each plot of every replication, a square ring was placed. The tillers fall inside the ring were counted. The observation was recorded at the time of harvesting.

\section{Spike length}

Ten spikes were selected randomly at the time of maturity in each treatment of every replication. Spike length was measured in $\mathrm{cm}$ from lower spike node up to tip of the panicle and averaged.

\section{Number of seeds spike $e^{-1}$}

Ten spikes were selected randomly at the time of maturity in each treatment of every replication.

After this process each spike of every replication was hand threshed separately and number of seeds spike $^{-1}$ was counted and averaged.

\section{Biomass yield plot $^{-1}$}

At field maturity experimental plot of each treatment of every replication was harvested by sickle. Harvested lot each plot was weighed in $\mathrm{kg}$.

\section{Grain yield per plot (kg)}

At field maturity experimental plot of each treatment of every replication was harvested by sickle and it was threshed and cleaned. Seed lot of each plot was weighed in $\mathrm{kg}$.

\section{0 seed weight}

A composite sample of about $100 \mathrm{~g}$ was drawn from graded seed lot of each treatment of every replication from which 1000 seeds were randomly taken out and counted. The counted samples were weighed in $\mathrm{g}$ up to two decimal places with the help of digital balance.

\section{Results and Discussion}

\section{Effect on day to heading and plant height}

The value related to effect of zinc on day to heading and plant height in variety K307 and K1006 were recorded. 


\section{Effect of variety}

The data regarding effect of variety on day to heading the variety K1006 significantly superior as compared to K307 and the effect of variety on plant height was non-significant deference. Numerically variety K1006 $(84.95 \mathrm{~cm})$ was superior as compared to K307 $(84.76 \mathrm{~cm})$.

\section{Effect of doses}

The different doses of zinc did not show the any significant effect on day to heading and plant height was significant effected by zinc application. However, Numerically treatment $\mathrm{Zn}_{0}$ (0\% zinc solution) exhibited least plant height $(83.52 \mathrm{~cm})$ while maximum $(86.61 \mathrm{~cm})$ was reported in treatment $\mathrm{Zn}_{4}(2 \%$ zinc solution) table-1 and it was at par to $\mathrm{Zn} 3(1.5 \%)$ with value of $85.24 \mathrm{~cm}$.

\section{Interaction effect}

Interaction of doses and variety did not show the any significant effect on days to heading and Interaction of variety and zinc showed significant differences with respect to plant height. Statistically minimum plant height $(82.92 \mathrm{~cm})$ was measured in $\mathrm{K} 307 \mathrm{xZn} 0$ and maximum $(86.85 \mathrm{~cm})$ was recorded in the combination $\mathrm{K} 307 \mathrm{XZn} \mathrm{n}_{4}$. The combination $\mathrm{K} 307 \mathrm{XZn} \mathrm{n}_{4}$ and $\mathrm{K} 1006 \mathrm{XZn} \mathrm{n}_{4}$ was showed at par.

\section{Effect on leaf area index at 60 and 90 das}

\section{Effect of variety}

The two different wheat varieties showed significant effect on leaf area index at 60 DAS. The variety K1006 (2.56) exhibited significant difference from the variety K307 (2.48) and leaf area index at 90 days after sowing (DAS) were statistically analysed non-significant difference was found between variety K307 and K1006.

\section{Effect of doses}

The zinc application had significant effect on leaf area index at 60 DSA. The dose $\mathrm{Zn}_{4}(2 \%$ zinc solution) had differed significantly from the rest of the doses applied. Enhancement in the leaf area index at 60 DAS was accompanied by increase in doses of zinc. Highest LAI at 60 DAS (2.58) and 90 DAS (3.61) was observed in $\mathrm{Zn}_{4}$ (2\%) while lowest (2.47) and (3.49) was found in control.

\section{Interaction effect}

Interaction of zinc and variety showed significant differences with respect to leaf area index at 60 DAS and90 DAS. Statistically lowest (2.46) and (3.48) was recorded in $\mathrm{K} 307 \mathrm{xZn} 0$ and maximum (2.63) and (3.63) was recorded in the combination K1006xZn4.

Effect on chlorophyll intensity and chlorophyll fluorescence

\section{Effect of variety}

It is obvious from the two different wheat variety showed significant effect on chlorophyll intensity. It is perceptible from in variety K307 (46.16) exhibited superior from the variety K1006 (41.69) and the varietal effect was show non-significant inchlorophyll fluorescence.

\section{Effect of doses}

It is clear that the application of zinc significantly influence the chlorophyll intensity and maximum chlorophyll intensity $(45.53 \%)$ and chlorophyll fluorescence $\mathrm{w}(0.758)$ was recorded in $\mathrm{Zn}_{4}(2 \%$ zinc solution) as compare to control $\mathrm{Zn}_{0}(40.77 \%)$ and (0.737). 


\section{Interaction effect}

Interaction of zinc and variety showed significant differences with respect to chlorophyll intensity and chlorophyll fluorescence. Statistically lowest (38.20\%) and (0.733) was recorded in $\mathrm{K} 1006 \times \mathrm{Zn} 0$ and maximum (49.47\%) and (0.761) was recorded in the combination K307xZn4. Simillar result found in Zhao et al., (2003), Nataraja et al., (2006).

\section{Effect on biological yield and seed yield per plot (kg)}

\section{Effect of variety}

The data obtained on biological yield per plot were statistically analysed. Both the varieties did not show any significant difference on biological yield per plot. However, numerically K1006 was superior over K307 and both the varieties had showed significant effect on seed yield per plot $(\mathrm{kg})$. The variety K1006 $(2.29 \mathrm{~kg})$ was statistically superior over the K307 (1.92kg).

\section{Effect of doses}

It is clear from the table-5 that zinc application has significant effect on biological yield. The treatment $Z_{1}, Z_{2}, Z_{3}$, and $Z_{4}$ showed statistically superiority over the control $\mathrm{Zn}_{0}$. Increasing trends in biological yield per plot were observed as the zinc doses were increased. Maximum biological yield was observed in $\mathrm{Zn}_{4}(9.91 \mathrm{~kg})$ and $(2.43 \mathrm{~kg})$ as compared to control $(8.29 \mathrm{~kg})$ and $(1.68 \mathrm{~kg})$.

\section{Interaction effect}

Interaction of zinc and variety showed the significant effect on biological yield. Maximum biological yield was observed in K307xZn4 (10kg) while minimum was recorded in K1006xZn0 $(8.08 \mathrm{~kg}$ and the interaction of zinc doses and variety did not influence the seed yield per plot. Similar results havebeen reported by Singh et al., (1999), Sharma and Bapat (2000), Yadav et al., (2002).

\section{Effect on 1000 grain weight (gm) and number of tillers $\mathbf{m}^{-2}$}

\section{Effect of variety}

It is obvious from the the variety $\mathrm{K} 307$ and K1006 showed significant effect on 1000 grain weight $(\mathrm{gm})$ number of tillers per $\mathrm{m}^{-2}$. The variety K1006 (42.87gm) and (349.3) was superior as compare K307 (41.27gm) and (340.2).

\section{Effect of doses}

The zinc application has influenced the 1000 grain weight and number of tillers per $\mathrm{m}^{2}$. Treatment $\mathrm{Zn}_{0}, \mathrm{Zn}_{1}, \mathrm{Zn}_{2}, \mathrm{Zn}_{3}$, and $\mathrm{Zn}_{4}$ showed significant difference to each other while all these treatments differed significantly from the treatment $\mathrm{Zn}_{4}$. Increasing trends in 1000 seed weight and number of tillers per $\mathrm{m}^{2}$ was observed as the zinc level increased. Respectively maximum (43.65gm) and (353.75) was reported in the treatment $\mathrm{Zn}_{4}$ as compare to control $(40.9 \mathrm{gm})$ regarding 1000 grain weight was recorded.

\section{Interaction effect}

The interaction of zinc doses and varieties showed significant effect on 1000 seed weight and number of tillers per $\mathrm{m}^{-2}$. Statistically maximum 1000 seed weight $(44.30 \mathrm{gm})$ and number of tillers per $\mathrm{m}^{-2}$ (357) was measured in K1006xZn4 and minimum (39.90gm) and (327) was recorded in the combination K307xZn0.Similar results havebeen reported by Singh et al., (1999), Sharma and Bapat (2000), Dewal and Pareek (2004),Sharma and Agarwal (2008) 
Table.1 Effect of different doses of zinc on Days to heading and Plant height $(\mathrm{cm})$ of wheat variety $\mathrm{K} 307$ and $\mathrm{K} 1006$

\begin{tabular}{|c|c|c|c|c|c|c|}
\hline \multirow{2}{*}{$\begin{array}{l}\text { Variety } \\
\text { Doses }\end{array}$} & \multicolumn{2}{|c|}{ Day to heading } & \multirow[b]{2}{*}{ Mean } & \multicolumn{2}{|c|}{ Plant height (cm) } & \multirow[b]{2}{*}{ Mean } \\
\hline & K307 & K1006 & & K307 & K1006 & \\
\hline $\mathbf{Z n}_{0}(\mathbf{0} \%$ solution $)$ & 83 & 85 & 84.0 & 82.92 & 84.12 & 83.52 \\
\hline $\mathrm{Zn}_{1}(\mathbf{0 . 5 \%}$ solution $)$ & 83 & 84 & 83.5 & 84.60 & 84.48 & 84.54 \\
\hline $\mathrm{Zn}_{2}$ (1\% solution) & 84 & 83 & 83.5 & 84.19 & 84.54 & 84.36 \\
\hline $\mathrm{Zn}_{3}(1.5 \%$ solution $)$ & 83 & 84 & 83.5 & 85.25 & 85.23 & 85.24 \\
\hline $\mathrm{Zn}_{4}(\mathbf{2 \%}$ solution $)$ & 84 & 84 & 84.0 & 86.85 & 86.38 & 86.61 \\
\hline \multirow[t]{2}{*}{ Mean } & 83.4 & 84.0 & & 84.76 & 84.95 & \\
\hline & SE (diff) & CD (0.05) & & SE (diff) & CD (0.05) & \\
\hline $\mathbf{V}$ & 0.32 & 0.67 & & 0.36 & NS & \\
\hline D & 0.51 & NS & & 0.57 & 1.21 & \\
\hline VxD & 0.71 & NS & & 0.81 & 1.71 & \\
\hline
\end{tabular}

Table.2 Effect of different doses of zinc on Leaf area index at 60 and 90 DAS of wheat variety K307 and K1006

\begin{tabular}{|c|c|c|c|c|c|c|}
\hline \multirow{2}{*}{$\begin{array}{l}\text { Variety } \\
\text { Doses }\end{array}$} & \multicolumn{2}{|c|}{ Leaf area index at 60 DAS } & \multirow[b]{2}{*}{ Mean } & \multicolumn{2}{|c|}{ Leaf area index at 90 DAS } & \multirow[b]{2}{*}{ Mean } \\
\hline & K307 & K1006 & & K307 & K1006 & \\
\hline $\mathrm{Zn}_{0}(\mathbf{0 \%}$ solution $)$ & 2.46 & 2.48 & 2.47 & 3.50 & 3.48 & 3.49 \\
\hline $\mathrm{Zn}_{1}(\mathbf{0 . 5 \%}$ solution $)$ & 2.45 & 2.56 & 2.50 & 3.55 & 3.60 & 3.57 \\
\hline $\mathrm{Zn}_{2}$ (1\% solution) & 2.50 & 2.55 & 2.52 & 3.55 & 3.60 & 3.57 \\
\hline $\mathrm{Zn}_{3}(1.5 \%$ solution $)$ & 2.48 & 2.60 & 2.54 & 3.57 & 3.57 & 3.57 \\
\hline $\mathrm{Zn}_{4}(2 \%$ solution $)$ & 2.53 & 2.63 & 2.58 & 3.60 & 3.63 & 3.61 \\
\hline \multirow{2}{*}{ Mean } & 2.48 & 2.56 & & 3.55 & 3.57 & \\
\hline & SE (diff) & CD (0.05) & & SE (diff) & CD (0.05) & \\
\hline $\mathbf{V}$ & 0.01 & 0.03 & & 0.01 & NS & \\
\hline D & 0.02 & 0.04 & & 0.01 & 0.02 & \\
\hline VxD & 0.03 & 0.06 & & 0.02 & 0.03 & \\
\hline
\end{tabular}

Table.3 Effect of different doses of zinc on Chlorophyll intensity and Chlorophyll fluorescence of wheat variety K307 and K1006

\begin{tabular}{|c|c|c|c|c|c|c|}
\hline \multirow{2}{*}{$\begin{array}{l}\text { Variety } \\
\text { Doses }\end{array}$} & \multicolumn{2}{|c|}{ Chlorophyll intensity } & \multirow[b]{2}{*}{ Mean } & \multicolumn{2}{|c|}{ Chlorophyll fluorescence } & \multirow[b]{2}{*}{ Mean } \\
\hline & K307 & K1006 & & K307 & K1006 & \\
\hline $\mathbf{Z n}_{0}(0 \%$ solution $)$ & 43.35 & 38.20 & 40.77 & 0.733 & 0.741 & 0.737 \\
\hline $\mathrm{Zn}_{1}(0.5 \%$ solution $)$ & 48.97 & 41.20 & 45.08 & 0.749 & 0.745 & 0.747 \\
\hline $\mathrm{Zn}_{2}(1 \%$ solution $)$ & 44.05 & 41.60 & 42.82 & 0.752 & 0.747 & 0.749 \\
\hline $\mathrm{Zn}_{3}(1.5 \%$ solution $)$ & 45.00 & 45.85 & 45.42 & 0.753 & 0.748 & 0.750 \\
\hline $\mathrm{Zn}_{4}(2 \%$ solution $)$ & 49.47 & 41.60 & 45.53 & 0.761 & 0.756 & 0.758 \\
\hline \multirow[t]{2}{*}{ Mean } & 46.168 & 41.69 & & 0.749 & 0.747 & \\
\hline & SE (diff) & CD (0.05) & & SE (diff) & CD (0.05) & \\
\hline V & 0.72 & 1.51 & & 0.00 & NS & \\
\hline D & 1.14 & 2.39 & & 0.01 & 0.01 & \\
\hline VxD & 1.61 & 3.38 & & 0.01 & 0.01 & \\
\hline
\end{tabular}


Table.4 Effect of different doses of zinc on Biological yield plot ${ }^{-1}(\mathrm{Kg})$ and Weight of seed yield $\operatorname{plot}^{-1}(\mathrm{~kg})$ of wheat variety K307 and K1006

\begin{tabular}{|c|c|c|c|c|c|c|}
\hline \multirow{2}{*}{$\begin{array}{l}\text { Variety } \\
\text { Doses }\end{array}$} & \multicolumn{2}{|c|}{ Biological yield plot $^{-1}(\mathrm{~kg})$} & \multirow[b]{2}{*}{ Mean } & \multicolumn{2}{|c|}{$\begin{array}{c}\text { Weight of seed yield plot }^{-} \\
{ }_{1}(\mathrm{~kg})\end{array}$} & \multirow[b]{2}{*}{ Mean } \\
\hline & K307 & K1006 & & K307 & K1006 & \\
\hline $\mathbf{Z n}_{0}(0 \%$ solution $)$ & 8.50 & 8.08 & 8.29 & 1.50 & 1.87 & 1.68 \\
\hline $\mathrm{Zn}_{1}(0.5 \%$ solution $)$ & 8.53 & 8.87 & 8.70 & 1.67 & 2.37 & 2.02 \\
\hline $\mathrm{Zn}_{2}(1 \%$ solution $)$ & 8.58 & 9.47 & 9.02 & 2.05 & 2.37 & 2.21 \\
\hline $\mathrm{Zn}_{3}(1.5 \%$ solution $)$ & 9.03 & 9.50 & 9.26 & 2.03 & 2.37 & 2.20 \\
\hline $\mathrm{Zn}_{4}(2 \%$ solution $)$ & 10.00 & 9.83 & 9.91 & 2.37 & 2.50 & 2.43 \\
\hline \multirow[t]{2}{*}{ Mean } & 8.92 & 9.15 & & 1.92 & 2.29 & \\
\hline & SE (diff) & CD (0.05) & & SE (diff) & CD (0.05) & \\
\hline $\mathbf{V}$ & 0.16 & NS & & 0.10 & 0.20 & \\
\hline D & 0.25 & 0.53 & & 0.15 & 0.32 & \\
\hline VxD & 0.36 & 0.75 & & 0.21 & NS & \\
\hline
\end{tabular}

Table.5 Effect of different doses of zinc on 1000 grain weight (gm) and No. of tillers $\mathrm{m}^{-}$ ${ }^{2}$ fluorescence of wheat variety K307 and K1006

\begin{tabular}{|c|c|c|c|c|c|c|}
\hline \multirow{2}{*}{$\begin{array}{l}\text { Variety } \\
\text { Doses }\end{array}$} & \multicolumn{2}{|c|}{1000 grain weight (gm) } & \multirow[b]{2}{*}{ Mean } & \multicolumn{2}{|c|}{ No. of tillers $\mathbf{~ m}^{-2}$} & \multirow[b]{2}{*}{ Mean } \\
\hline & K307 & K1006 & & K307 & K1006 & \\
\hline $\mathbf{Z n}_{0}(\mathbf{0 \%}$ solution $)$ & 39.90 & 41.90 & 40.9 & 327.0 & 340.5 & 333.75 \\
\hline $\mathrm{Zn}_{1}(\mathbf{0 . 5 \%}$ solution $)$ & 40.40 & 42.90 & 41.65 & 333.5 & 349.0 & 341.25 \\
\hline $\mathrm{Zn}_{2}(1 \%$ solution $)$ & 41.25 & 42.85 & 42.05 & 347.5 & 350.0 & 348.75 \\
\hline $\mathrm{Zn}_{3}(1.5 \%$ solution $)$ & 41.80 & 42.40 & 42.1 & 342.5 & 350.0 & 346.25 \\
\hline $\mathbf{Z n}_{4}(2 \%$ solution $)$ & 43.00 & 44.30 & 43.65 & 350.5 & 357.0 & 353.75 \\
\hline \multirow[t]{2}{*}{ Mean } & 41.27 & 42.87 & & 340.2 & 349.3 & \\
\hline & SE (diff) & CD (0.05) & & SE (diff) & CD (0.05) & \\
\hline $\mathbf{V}$ & 0.56 & 1.40 & & 1.40 & 2.95 & \\
\hline D & 0.89 & 2.22 & & 2.22 & 4.67 & \\
\hline VxD & 1.26 & 3.14 & & 3.14 & 6.60 & \\
\hline
\end{tabular}

Table.6 Effect of different doses of zinc on Spike length $(\mathrm{cm})$ and number of seed per spike of wheat variety K307 and K1006

\begin{tabular}{|c|c|c|c|c|c|c|}
\hline \multirow{2}{*}{$\begin{array}{c}\text { Variety } \\
\text { Doses }\end{array}$} & \multicolumn{2}{|c|}{ Spike length (cm) } & & \multicolumn{2}{|c|}{ No of seed per spike } & \\
\cline { 2 - 6 } & $\mathbf{K 3 0 7}$ & $\mathbf{K 1 0 0 6}$ & Mean & K307 & K1006 & Mean \\
\hline $\mathbf{Z n}_{\mathbf{0}}$ (0\% solution) & 8.72 & 8.42 & 8.42 & 40.65 & 41.25 & 40.95 \\
\hline $\mathbf{Z n}_{\mathbf{1}}(\mathbf{0 . 5 \%}$ solution) & 8.81 & 8.45 & 8.63 & 45.88 & 49.78 & 47.83 \\
\hline $\mathbf{Z n}_{\mathbf{2}}$ (1\% solution) & 8.95 & 8.57 & 8.76 & 46.50 & 50.10 & 48.30 \\
\hline $\mathbf{Z n}_{\mathbf{3}}$ (1.5\% solution) & 8.46 & 8.53 & 8.49 & 49.25 & 51.25 & 50.25 \\
\hline $\mathbf{Z n}_{\mathbf{4}}$ (2\% solution) & 8.56 & 8.79 & 8.67 & 50.10 & 51.25 & 50.67 \\
\hline Mean & 8.7 & 8.5 & & 46.47 & 48.72 & \\
\hline & $\mathbf{S E}(\mathbf{d i f f})$ & $\mathbf{C D}(\mathbf{0 . 0 5}$ & & $\mathbf{S E}(\mathbf{d i f f})$ & $\mathbf{C D}(\mathbf{0 . 0 5})$ & \\
\hline $\mathbf{V}$ & 0.07 & 0.15 & & 0.29 & 0.62 & \\
\hline $\mathbf{D}$ & 0.11 & NS & & 0.47 & 0.98 & \\
\hline $\mathbf{V x D}$ & 0.16 & 0.33 & & 0.66 & 1.38 & \\
\hline
\end{tabular}


Effect on spike length (cm) and number of seed per spike

\section{Effect of variety}

The variety K307 and K1006 showed significant effect on spike length $(\mathrm{cm})$ and number of seed per spike. The variety K1006 (8.7) and (48.72)was superior as compare $\mathrm{K} 307$ (8.5) and (46.47).

\section{Effect of doses}

The effect of zinc doses did not show any significant effect on the spike length $(\mathrm{cm})$ and the application of zinc had significant effect on number of seed per spike. Control $\mathrm{Zn}_{0}$. ( $0 \% \mathrm{Zn}$ solution), $\mathrm{Zn}_{1}$ ( $0.5 \% \mathrm{Zn}$ solution), $\mathrm{Zn}_{2}$ ( $1 \% \mathrm{Zn}$ solution), $\mathrm{Zn}_{3}$ (1.5\% $\mathrm{Zn}$ solution) and $\mathrm{Zn}_{4}(2 \% \mathrm{Zn}$ solution) produced $40.95,47.83$, $48.30,50.25$ and 50.67 number of seed per spike, respectively.

Maximum $\mathrm{Zn}_{4}$ (50.67) number of seed per spike was recorded as compared to control (40.95). Non- significant difference between $\mathrm{Zn}_{3}$ (50.25)and $\mathrm{Zn}_{4}$ (50.67). According doses slightly increase the number of seed per spike.

\section{Interaction effect}

Interaction of variety and zinc doses showed significant effect on the spike length $(\mathrm{cm})$ and number of seed per spike. Statistically maximum $(8.95 \mathrm{~cm})$ and $(51.25)$ was measured in $\mathrm{c}$ and minimum $(8.42 \mathrm{~cm})$ and (40.65) was recorded in the combination K1006xZn0 (table-6).

The treatment combination $\mathrm{K} 307 \mathrm{xZn} 2$ and K307xZn1 showed at par. Similar results have been reported by Singh et al., (1999), Sharma and Bapat (2000),Kasturi krishna and Ahlawat (2000),Sharma and Agarwal (2008).

\section{References}

Dewal, G. S. and Pareek, R. G. (2004). Effect of phosphorus, sulphur and zinc on growth, yield and nutrient uptake of wheat (Triticumaestivum L.). Ind. J. Agron., 49(3): 160-162.

Kalayci, M.; Torun, B.; Eker, S.; Aydin, M.; Ozturk, L. and Cakmak, I. (1999). Grain yield, zinc efficiency and zinc concentration of wheat cultivars grown in a zinc-deficient calcareous soil in field and greenhouse. Field Crops Res., 63: 87-98.

Kasturikrishna, S. and Ahlawat, I.P.S. (2000). Effect of moisture stress and phosphorus, sulphur and zinc fertilizers on growth and development of pea (PisumsativumL.). Indian J. Agron., 45 (2): 353-356.

Marshner, H. (1995). Mineral Nutrition of Higher Plants $2^{\text {nd }}$ edition, Academic Press, London, pp.889.

Nataraja, T. H.; Halepyati, A. S.; Pujari, B. T. and Desai, B. K. (2006). Influence of phosphorus levels and micronutrients on physiological parameters of wheat (Triticum durum L.). Karnataka J. of Agric. Sci. 19 (3): 685-687.

Sharma, B. L. and Bapat, P. N. (2000). Levels of micronutrient cations in various plant parts of wheat as influenced by zinc and phosphorus application. $J$. of the Indian Society of Soil Sci. 48 (1): 130-134.

Sharma, Reena; Agarwal, Abha and Kumar, Sanjeev (2008). Effect of micronutrients on protein content and productivity of wheat (Triticumaestivum L.). Vegetos. 21 (1):51-53.

Shukla, S. K. and Warsi, A. S. (2000). Effect of sulphur and micronutrients on growth, nutrients content and yield of wheat (Triticumaestivam L.). Indian $J$. Agric. Res., 34 (3): 203-205.

Singh, R. S. P.;Pandey, R. D. and Thakur, S. S. (1999). Effect of different nutrient 
levels, zinc and FYM on wheat yield. $J$. of Applied Bio. 9 (1): 38-40.

Tisdale, S. L.; Nelson, W. L. and Beaten, J. D. (1984). Zinc in Soil Fertility and Fertilizers, $\quad 4^{\text {th }}$ Ed., Macmillan Publishing Company, New York, USA pp: 382-391.

Watson, D.J. (1947). Comparative physiological studies on growth of field crops. I. Variation in net assimilation rate and leaf area between species and varieties and within years. Ann. Bot.,11: 41-76.

Yadav, K. K.; Chhipa B. R.; Yadav, B. L.; Jat, N. L.; Pathan, A. R. K. and Panwar, N. R. (2002). Response of wheat to zinc fertilization under irrigation with different RSC water. Annuals Plant Soil Res. Inch: 151-154.

\section{How to cite this article:}

Devendra Kumar Singh, Meera Shrivastava, Vivek Kumar Patel, Ankit Singh and Abhay Kumar. 2020. The Effect of Different Levels of Zinc on Morpho-Physiological Parameters, Seed Yield Attributing Characters and Seed Quality of Wheat. Int.J.Curr.Microbiol.App.Sci. 9(05): 1765-1773. doi: https://doi.org/10.20546/ijcmas.2020.905.199 